\title{
Élise Voguet, Le monde rural du Maghreb central (XIVe-XVe siècles). Réalités sociales et constructions juridiques d'après les Nawāzil Māzūna. Bibliothèque Historique des Pays d'Islam 5, Collection dirigée par Christophe Picard et Pierre Vermeren, Paris: Publications de la Sorbonne, 2014, 512 p., ISBN-10: 2859447784, ISBN-13: 978-2859447786
}

Reviewed by Delfina Serrano Ruano, Spanish High Council for Scientific Research, Madrid, Spain, delfina.serrano@cchs.csic.es

https://doi.org/10.1515/islam-2018-0022

The book under review is based on the author's doctoral dissertation, presented at Paris 1 University in 2005. The resulting publication meets its aims with rigor and consistency: a collection of legal cases capable of shedding light on a subject in need of attention - the history of the medieval central Maghreb - has been put to contribution for the study of rural communities in that area. The book is not only a continuation but also a reminder of the significant contribution of French scholarship to the exploitation of Arabic legal sources for the social and economic history of the medieval Islamic West. Within this region, the study of the central Maghreb has been disadvantaged with respect to Ifrīqiya, the Far Maghreb and al-Andalus.

The book unfolds in three parts preceded by an introduction and completed by general conclusions (445-450), a table of abbreviations, bibliography, and a list of short biographies of the jurists mentioned in the collection ordered chronologically by their death dates plus indexes of places, persons, groups and subjects.

In the introduction (9-33), the author reviews the state of the art and justifies her selection of subject and sources, showing her awareness of the necessary precautions to be taken when using legal sources with purposes other than strict legal history. She declares to have paid special attention to the conditions in which the examined texts were produced and rightly notes that the terms applying to legal responsa like nawāzil (legal cases), fatāwa (legal assessments) and masā'il (legal questions) used to be employed interchangeably. The selection of one of these terms does not point to a jurist's intention to differentiate between theoretical and "real" cases. All the texts under these different labels provide, as the author observes, juridical views of realities that differ in their temporal distance from the jurists who transmitted them. The author is interested in observing how these cases reflect the jurists' role in managing everyday social life and in mediating between rural communities and the urban and political center (part III).

As it is common with this kind of literature, the fatwas involve a re-articulation of the circumstances at hand translating real world events to legal jargon, 
while the jurists do not always appear to know the respective circumstances in detail. The author sees also an attempt by the jurists to detach actual facts from their specific temporal and local context in order to lend them general relevance, though this is only partially the case with what Wael HALLAQ qualified as "secondary" fatwas - that is to say, edited and abridged by someone other than their authors - and does not always apply to other "primary" - fatwas transmitted in their original version - samples of the genre.

The source is titled al-Durar al-maknūna fī nawāzil Māzūna which VoGUET renders as "The hidden pearls from among the Nawāzil Māzūna”. The cases emerged from real situations reported to a judge (17) and were gathered by the 15th-century jurist Abū Zakariyyā' Yahyyā ibn Abī 'Imrān Mūsā ibn 'Īsā al-Maghīlī al-Māzūnī (d. 883/1478) to complete a former collection compiled by the author's father and drawing partially from Burzulì's voluminous collection, Jāmi ' masā'il al-ahkām. Conversely, some of the cases included in the Nawāzil are subsequently reproduced by al-Wansharīsī in his Míyār. Little is known about the younger al-Maghīlī other than that he witnessed the reigns of four Zayyānid sultans, a settled branch of the Berber tribe of the 'Abdulwadids who reigned between 834/1430 and 910/1504. One of them, Abū 'Abd Allāh Muhammad III al-Mutawakkil, was the most relevant to al-Maghīlī al-Māzūnī for it was this sultan who invited him to settle in Tlemcen where he became a leading member of the scholars of the capital.

The fatwas were issued either by Yahyā al-Maghīlī's direct masters or by other prominent contemporary jurists from Tlemcen, Tunis, Bougie and Alger. The list of consulted muftis is headed by Qāsim al-'Uqbānī of Tlemcen (d. 854/1450) who authors a quarter of all the fatwas in the collection. He is followed by Muhammad Ibn Marzūq (d. 842/1439) with 10\%, by Muhmmmad al- 'Uqbānī (d. 871/1467) with $3 \%$ and by others. Most of them performed relevant religious-legal positions like $q \bar{a}$ ḍì, chief $q \bar{a} d \underline{\imath} \bar{l}$, preacher, imām or madrasa teacher for the sultans in a time in which Fez started to decline as a center of Mālikī learning in favor of Tunis and Tlemcen.

Al-Māzūnī's role is thus one of transmission of the legal opinions of the jurists of his time in a move that VoGUET sees as a local appropriation of and accommodation to Mālikī doctrine in a region in constant change. The collection is not a mere juxtaposition of individual legal responsa but seems to be conceived as a vade mecum for al-Māzūnī's successors in the qā dịship of Mazouna, a position he occupied before settling in Tlemcen, where he died.

The Nawāzil Mazūna are organized into chapters, from rituals ('ibādāt) to social transactions (mu'àmalāt); blood crimes are treated under the heading of Masā'il mūjibāt al-jirāh, and banditry under that of crimes and torts (jināyāt). The collection had already been examined by both Jacques BERQUE, who described 
its main traits and called attention to its content, and Houari TouATI, who used it to investigate the role of the marabouts (murābițūn) and the chorfa (shurafā') in 15th-century central Maghreb. From a total of 700 fatwas contained in the manuscript,Voguet edits, translates into French and analyzes, 82 (see total list of contents in 22-23). The selected fatwas come from the part of the manuscript which runs from the chapter on sales to that on bequests (51-263). The author has judged those fatwas as being more interesting to address political, economic and spatial organization in rural central Maghreb than the others. From the above mentioned selection, most of the cases deal with claims and disputes for damages (masā'il al-ḍarar wa-l-da'āwì wa-l-khușūmāt), usurpation and plundering (al-ghașb wa-lta'addī).

Selections of this kind always pose problems and the author is ready to recognize that the result may only be "impressionist" or patchy, and that this ensemble will have to be completed by successive studies drawing on similar or different sources.

The analysis of the contents occupies the second part of the book, consisting of three chapters. Chapter one examines the data concerning territorial organization and how the divides between rural and urban spaces, sedentary and nomadic ways of life and agriculture and cattle breeding, are represented in the fatwas (267-335, see below paragraph I). The second chapter deals with the economic activities reflected in the fatwas and how the groups in place coped with natural disasters, famine and the instability brought on them by heavy payments imposed from outside; most of those economic activities were regulated according to customary practices (337-397, see below paragraph II). In the third chapter, the author observes the contribution of the jurists to the political, economic and social management of the area concerned (399-444, see below paragraph III). To refine her analysis VoGUET has used other similar compilations of legal cases and fatwas such as the aforementioned collections by al-Burzulī and al-Wansharīsī. Her assertion that al-Māzūnī was more oriented towards actual legal practice than the other two compilers is questionable; the difference between the three fatwa collections lies rather on al-Māzūnī's local focus by contrast with the global aspirations of the other two. Al-Māzūnī seems to have been motivated by the will to both accommodate Mālikî fiqh to central Maghrib and insert that region in the map of Mālikī history and tradition, as qā ḍ̄ 'Iyāḍ did three centuries earlier with his native Ceuta and the whole Far Maghrib region. Voguet says to have also consulted earlier compilations of fatwas issued by Ibn Rushd al-Jadd, Ibn Sahl and 'Iyāọ ibn Mūsā. Although she quotes it in the bibliography, she appears to be unaware of the existence of a Spanish translation and study of a whole collection of fatwas issued by 'Iyāọ in his position as muftī and qā dị (25) and does not see the relevance of this source for agricultural activities in the Maghreb. VogueT 
has also used other, not strictly legal sources contemporary to al-Māzūnī to contextualize her results such as travel accounts, chronicles, biographical literature, and a collection of Spanish documents. The latter consist mainly of official correspondence between the governors of cities conquered by the Spanish crown such as Oran and Algiers, and the 'Abdelwadid sultans of Tlemcen, the local tribal chiefs, and the royal chancellery in Spain. The author says to have been unable to consult the Arabic versions of the documents; a team of researchers of the CSIC is currently working on them. ${ }^{1}$

Voguet identified copies of the Nawāzil Māzūna in Tunis, Algeria and Morocco (37-46). The edition of her selection is based on four manuscripts, one from Algiers (ج), two from Rabat ( 3 and $ر$ ) and one from Tunis (ت) (47-48). The selection does not respond to the quality of the manuscripts in question, among which manuscript $ق$ is the oldest one with outstanding calligraphy, but rather to the conditions of her obtaining the copies. The folio numbers to which the footnotes refer in the second part of the book correspond to the $\mathrm{manuscript.}$ The French translation follows immediately after the critical edition of each individual fatwa headed by the name of the mufti , his local and temporal coordinates, and the location of the item in the four different manuscripts. I assume the numbers introducing each new item in the selection correspond to the order of each new fatwa in the original manuscripts. As far as I can judge, the translations are excellent.

The conclusions are not sensational, especially for the reader already familiar with Islamic legal sources, but they are extremely helpful and represent an important step further in the study of rural communities in the pre-modern Islamic West:

I. The question of the legal status of the Maghreb, and of whether it was conquered by force or passed to Islamic rule by means of a peace treaty ('unwatan/ șulhan) is not relevant in practice except for justifying a certain form of taxation in accordance with legal doctrine. This question gives way to the differentiation between land controlled by a central power in which economic activities are subject to taxes, and land that escapes that control and Mālikī doctrine alike. This is the main reason for the jurists' attempt to favor sedentary ways of life and organization. The nawāzil privilege the representations of the jurists, not people's conception of their habitat. The terms of 'arab, pl. a'rāb as they appear

1 The results of this project have not yet seen the light. Meanwhile, see a general overview by M. Meouak in "Les documents en arabe dialectal de l'“Archivo General de Simancas": une source inestimable pour l'histoire du Maghreb central aux XVI et XVII e siècles”, Studi Magrebini, nuova serie, V (2007): 161-175. 
in the nawāzil seem to refer to tribes with real or presumed Arab origin and specifically to Hilālī tribes which were forced to migrate from Egypt to the Maghreb by the Fāṭimid caliph al-Mustanșir bi-Llāh in the middle of the 5th/11th century. A number of cases evoke some prominent figures among the Hilāli tribes who after having carried out a life of plundering and violence repent and shared their properties acquired in such manner. The terminology about land, habitat and social groups is polysemic and imprecise, and cannot be relied on to establish differences or categorizations or to grasp the relationship between family and tribal groups. Such types of relationships can be observed mainly through discussions about inheritance rights and the distribution of responsibility for crimes and torts. The term nasab, for example, is not used in the nawāzil to connect an individual with his kin group but emerges in connection with bequests in the benefit of someone who is not a paternal relative or descendant of the endower (329-330), or else, appears in connection with shārīfism, whereupon the question emerges of how sharifism is established, either exclusively by paternal or also by maternal kinship. The shurafā' appear very rarely in the Nawāzil and do not thus seem to have been very influential in al-Māzūnī's times. The role of spokesmen for the people of the countryside that might have been expected from them is rather performed by the murābițūn. When the people from the countryside are mentioned in the fatwas it is not because of their ethnic designation or their language but rather because of their ways of life and activities.

II. Apart from the many cases illustrating cattle breeding and nomadism, a singular aspect of the collection is given by the cases dealing with salt marshes, abundant in central Maghreb, as well as iron, copper and silver mines. This is in contrast with the lack of information about the uses to which salt was put after its extraction (381-384) either as condiment, preserver or tradeable currency in the gold and slaves markets. The mines, we are told, were exploited by the local tribes and the fatwas confirm the attempt by the Sultan to avail himself of his right to exploit them in first instance when the territory in which they are located was not deemed to have passed to Islam peacefully. This situation does not differ much from that of 12th-century Cordoba, yet in the latter case and in contrast with Central Maghrib, the "fiqh" did not always support the position of the ruler. Central Maghribi jurists accepted the renting of the mines in exchange for a part of the yield, a practice they preferred over renting for a given period of time. The author regrets the scarce information provided by the source on extraction techniques and the subsequent use given to the yield, apart from some farmers' and craftsmen's tool manufacturing, or as raw exchange currency. The cases are also extremely useful to study arbitration and amicable settlement of disputes though there seems to be some confusion between the functions performed by the non-

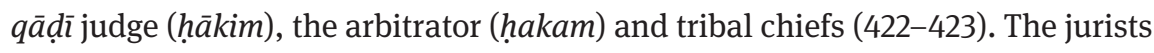


tried to bring custom into the orbit of fiqh as much as possible, at times justifying their validity by way of necessity (darūra). Very often the jurists' action over the customs regulating economic activities and local forms of association and distribution of work, resources and infrastructure involved the compilation (codification is a problematic term in the context we are dealing with and should be avoided) of these customs in order to have them under control. Most of these customary contractual forms had been addressed by Jacques BERQUE.

III. The author observes the relationships and conflicts between the different social groups in place, and between these groups and the central power. The most important group was composed of the murābitūn or eremitic self-appointed soldiers living in a sanctuary or in the tomb of a saint ( $z$ äwiya). Given their acute weakness, the 'Abdelwadid sultans opted for conciliation with them and with the Arab Bedouin tribes by means of territorial concessions (iqța' 'ât). The murābițūn also appear as beneficiaries of fiscal exemptions (432-443). They are thus important economic actors performing also a relevant role as mediators between the Bedouins and the central power to the detriment of their religious functions, which are scarcely represented in the nawāzil. Unsurprisingly, the jurists refuse to acknowledge any religious authority to them, though their rejection of the murābitūn is less pronounced than their rejection of the 'arāb. Indeed, the murābițūn are occasionally presented in the fatwas as offering poles of stability at the local level.

The sultan is often considered unjust because of the illegal taxes he collects from the people. The jurists adopt a critical position towards central authority at the same time they play as mediators between it and the bulk of the population. Also, the jurists claim for themselves the right to define the role corresponding to each social group in the ideal social order. The Bedouins are misrepresented by the jurists as vile looters and enemies of Islam, and caution against taking this image at face value is advised by VoguET. The local representatives of central power (the 'âmils) appear rather frequently in the nawāzil where they are often described as unjust plunderers who abuse their power; the same remarks apply to tribal chiefs or provincial $q \bar{a}$ 'ids all enjoying a high degree of autonomy due to the sultans' inability to keep them under control.

In regard to the judges, their jurisdiction was normally assimilated with central power, imprecision in their attributions and overlap with those of other actors in place being the main traits characterizing the judges' performance.

In this time and region, the sultan plays an important role as founder of pious endowments for the construction and maintenance of public infrastructure like walls, roads, markets, etc. Voguet emphasizes the frequent occurrence of the term mașlaha (general interest) in jurists' descriptions of that role, especially in fatwas issued by the end of the 14th and the beginning of the 15th century. Though 
not yet sufficiently argued, she sees a relation between jurists' involvement in public endowments and the concept of general interest as a sign of the increasing institutional functions performed by the jurists within the sultanic structure.

\section{Andreas Wilde, What is Beyond the River? Power, Authority and Social Order in Transoxiana, $18^{\text {th }}-19^{\text {th }}$ Centuries, xvi, $1101 \mathrm{~S}$. in drei Bänden, fortlaufend paginiert, Wien: Verlag der Österreichischen Akademie der Wissenschaften, 2016 (Veröffentlichungen zur Iranistik Nr. 80). ISBN 978-3-7001-7866-8.}

Besprochen von Jürgen Paul, Universität Hamburg, Hamburg, juergen.paul@uni-hamburg.de https://doi.org/10.1515/islam-2018-0023

Vor nunmehr über 20 Jahren zeichnete Yuri BREGEL (1925-2016) ein düsteres Bild westlicher (englischsprachiger) Publikationen zur Geschichte Zentralasiens. Nachdem er eine Reihe von sowjetologisch angelegten Arbeiten sehr kritisch besprochen hatte, stellte er fest, dass für die gesamte Periode von den Timuriden bis zum Ende der činggisidischen Herrschaft, also für das 16.-18. Jahrhundert, nur ganz wenige Autoren mit ernstzunehmenden Publikationen aufgetreten sind, darunter Robert McChesney, Audrey Bu RTon und er selbst. ${ }^{1}$ Das hat sich seither doch sehr geändert. Zahlreiche grundlegende Arbeiten sind seither erschienen, $\mathrm{zu}$ viele, um sie aufzuführen. Das besprochene Werk reiht sich hier ein.

WILDEs Arbeit geht auf eine Bonner Dissertation zurück, die 2010 eingereicht und 2012 verteidigt wurde. Sie ist im Rahmen des Projekts Local Governance and Statehood in the Amu Darya Borderlands (2005-2011) entstanden, ein im Wesentlichen gegenwartsbezogen orientiertes Vorhaben; im Mittelpunkt stand die Frage nach Gegenwart und Zukunft der Staatlichkeit in der Region. WiLDEs Fragestellung ist von derjenigen des Gesamtvorhabens inspiriert.

WILDE beginnt mit einer theoretischen Einleitung zum zentralen Konzept von social order; den Begriff „Staat“ und den traditionellen Gegenpol „Stamm“ will er vermeiden. Social order ist die Art, wie Menschen auf der Grundlage einer Weltsicht ihre Angelegenheiten organisieren. Im Buch selbst werden dann vor allem

1 BRegel, Yuri, Notes on the Study of Central Asia, Bloomington (Indiana Research Institute for Inner Asian Studies), 1996 (Papers on Inner Asia: 28), bes. S. 58. Er nennt besonders Robert MCChesneys Waqf in Central Asia (Princeton 1991). Audrey Burtons The Bukharans (London 1997) ist nach BREGELS polemischer Arbeit erschienen; sie hatte aber einige Jahre zuvor in der von BREgEL herausgegebenen Serie Papers on Inner Asia eine kürzere Studie vorausgeschickt: Audrey BuRTON, Bukharan Trade 1558-1718, Bloomington (Indiana University Research Institute for Inner Asian Studies), 1993 (Papers on Inner Asia: 25). 